\title{
The Implementation of Product Marketing Strategy of PT. Asuransi Umum Bumi Putera Muda 1967 at Dumai Branch
}

\author{
Variza Aditiya \\ Sekolah Tinggi Ilmu Administrasi Lancang Kuning Dumai \\ e-mail: variza.adit.stiadmi@gmail.com
}

\begin{abstract}
The purpose of this study was to see the implementation of the marketing strategy of PT. Asuransi Umum Bumi putera Muda 1967 at Dumai Branch. The theory used is according to Lovelock, namely: Product, Price, Place, Promotion, People, Physical Evidence and Process. This study uses a combined research method that is using descriptive methods with a quantitative approach. Types and sources of data in this study are primary data and secondary data. Data collection techniques used were questionnaires and interviews. Data analysis was performed using descriptive statistical analysis techniques. One of the sampling techniques used in determining individual samples is purposive random sampling. The results of 97 respondents showed that respondents' attitudes about the Marketing Strategy variable based on the calculation of the total questionnaire score were in the Good category with a score of 7,985 with a percentage of $74.83 \%$. Analysis of respondents' attitudes about Product Marketing Strategy Analysis at PT. Asuransi Umum Bumi putera Muda 1967 at Dumai Branch showed a positive attitude. The factors that influence the Product Marketing Strategy at PT. Asuransi Umum Bumi putera Muda 1967 at Dumai Branch is Lack of utilization of the use of brochures, Lack of socialization in following the expo and the many requirements in matters of claims and Lack of certainty of time in service.
\end{abstract}

Keywords: Implementation, Strategy, Marketing, insurance

\section{Abstrak}

Tujuan penelitian ini untuk melihat pelaksanaan strategi pemasaran PT. Asuransi Umum Bumi putera Muda 1967 Cabang Dumai. Teori yang digunakan adalah menurut Lovelock yaitu: Product, Price, Place, Promotion, People, Physical Evidence dan Process. Penelitian ini menggunakan metode penelitian gabungan yaitu menggunakan metode deskriptif dengan pendekatan kuantitatif. Jenis dan sumber data dalam penelitian ini adalah data primer dan data sekunder. Teknik pengumpulan data yang digunakan adalah angket dan wawancara. Analisis data dilakukan dengan teknis analisis statistik deskriptif. Salah satu teknik sampling yang digunakan dalam menentukan sampel individu adalah purposive random sampling. Hasil penelitian dari 97 responden menunjukkan bahwa sikap responden tentang variabel Strategi Pemasaran berdasarkan perhitungan total skor angket berada pada kategori Baik dengan skor 7.985 dengan persentase 74,83\%. Analisis dari sikap responden tentang Analisis Strategi Pemasaran Produk pada PT. Asuransi Umum Bumi putera Muda 1967 Cabang Dumai menunjukkan sikap yang positif. Adapun faktor-faktor yang mempengaruhi Strategi Pemasaran Produk pada PT. Asuransi Umum Bumi putera Muda 1967 Cabang Dumai adalah Kurangnya pemanfaatan penggunaan brosur, Kurangnya sosialisasi dalam mengikuti ekspo dan Banyaknya persyaratan dalam urusan klaim dan Kurangnya kepastian waktu dalam pelayanan.

Kata Kunci : Pelaksanaan, Strategi, Pemasaran, asuransi 


\section{INTRODUCTION}

Insurance is a willingness to decide the certain small loss as the substitution of uncertain big loss. In insurance, the insured should pay premium causing the risk possibility moved to the insurance company. Furthermore, insured get a protection of possible loss happened.

One of insurance company main activity is moving the indivual risk to the insurance company. In another word, insurance company will be the guarantor for the insured if there is a risk in an activity such as died, accident, etc. Goes along with the public interest and climate improvement in insurance, the competition of insurance companies increases significantly. Best marketing strategy becomes a way for the company to face the competition.

Asuransi Jiwa Bersma (AJB) Bumi putera is a pioneer of first and oldest national life insurances in Indonesia. Eventhough it had a brand image in public, Asuransi Jiwa Bersama (AJB) Bumiputera keep maintainance the customers' services quality. So, it is ready for competing with the foreign insurance companies. The potency of this business attracts foreign incurance company to participate and add options for the public to choose the best insurance. It finaly causes a high competition in insurance industry.

In marketing insurance produk, PT. Asuransi Bumiputera Muda 1967 Cabang Dumai has some strategy implemented. This following table presents the strategies applied by PT. Asuransi Bumi putera Muda 1967 Cabang Dumai.

\section{Marketing Strategy Planned}

\section{PT. Asuransi Umum Bumi putera Muda 1967 Cabang Dumai}

\begin{tabular}{|c|c|c|c|}
\hline Conventional & Retail Segment & Corporation Segment & Service Level \\
\hline Product & $\begin{array}{l}\text { Simple, simply } \\
\text { understandable }\end{array}$ & $\begin{array}{l}\text { Complete, quick service } \\
\text { Comprehensive guarantee and } \\
\text { Product is up to date }\end{array}$ & Standard, Quick Service \\
\hline Price & $\begin{array}{l}\text { Medium Price (tend } \\
\text { to be high) } \\
\text { Commision: high } \\
\text { Bonus: Portofolio }\end{array}$ & $\begin{array}{l}\text { Medium price and } \\
\text { competitive (tend to be cheap) } \\
\text { Comission: medium } \\
\text { Bonus: result business } \\
\text { Profit sharing }\end{array}$ & $\begin{array}{l}\text { Medium price tend to be } \\
\text { high } \\
\text { discount: high } \\
\text { Bonus: result business } \\
\text { Profit sharing }\end{array}$ \\
\hline Promotion & $\begin{array}{l}\text { Socialization in } \\
\text { AJB } \\
\text { Simple brochures, } \\
\text { high in quantity, } \\
\text { few mass media, } \\
\text { counter, expo } \\
\text { Sponsorship AJB }\end{array}$ & $\begin{array}{l}\text { Proposal Lux } \\
\text { Company Profile Lux } \\
\text { Video Profile } \\
\text { Mass Media } \\
\text { Sponsorship } \\
\text { Personal Entertainment }\end{array}$ & $\begin{array}{l}\text { Proposal Lux } \\
\text { Company Profile Lux } \\
\text { Video Profile } \\
\text { Mass Media } \\
\text { Sponsorship } \\
\text { Personal Entertainment }\end{array}$ \\
\hline People & $\begin{array}{l}\text { Presentable and } \\
\text { humble } \\
\text { Senior high school } \\
\text { graduate } \\
\text { Skilled dan diligent } \\
\text { AJB ex }\end{array}$ & $\begin{array}{l}\text { Presentable } \\
\text { Golf qualified } \\
\text { Min D3 } \\
\text { Supple } \\
\text { A good presenter } \\
\text { Having wide product concept }\end{array}$ & $\begin{array}{l}\text { Uniform } \\
\text { Min D3 } \\
\text { Supple } \\
\text { A good presenter } \\
\text { Having wide product concept } \\
\text { Civil servant retired } \\
\text { Undertand about regulation } \\
\text { \& government bureaucracy }\end{array}$ \\
\hline
\end{tabular}

Data Source: PT. Asuransi Umum Bumi putera Muda 1967 at Dumai Branch, 2016 
To achieve the set profit, company insurance management should implement a good marketing strategy. Profit achievement will preserve and improve the company sustainability. This following table presents the strategy applied by PT. Asuransi Umum Bumiputera Muda 1967 at Dumai Branch.

Marketing Strategy Implementation of

PT. Asuransi Umum Bumi putera Muda 1967 at Dumai Branch

\begin{tabular}{|c|c|c|c|}
\hline Conventional & Retail Segment & Corporation Segment & Service Level \\
\hline Product & $\begin{array}{c}\text { Simple, } \\
\text { understandable }\end{array}$ & $\begin{array}{l}\text { Complete, Tailor Made, and } \\
\text { quick service } \\
\text { High Guarantee dan Product } \\
\text { up to date }\end{array}$ & $\begin{array}{l}\text { Standard, quick service } \\
\text { (bonding) }\end{array}$ \\
\hline Price & $\begin{array}{l}\text { Price is based on } \\
\text { product. }\end{array}$ & $\begin{array}{l}\text { Competitor has an important } \\
\text { role in deciding the price. }\end{array}$ & $\begin{array}{l}\text { Medium price tends to high } \\
\text { Commision/discount : high } \\
\text { Bonus: result business } \\
\text { Profit sharing }\end{array}$ \\
\hline Promotion & $\begin{array}{c}\text { Bumida cabang } \\
\text { Dumai never join an } \\
\text { expo }\end{array}$ & $\begin{array}{l}\text { Bumida cabang Dumai never } \\
\text { use mass media and video } \\
\text { profile. }\end{array}$ & $\begin{array}{l}\text { Bumida Cabang Dumai } \\
\text { never use mass media and } \\
\text { video profile. }\end{array}$ \\
\hline People & $\begin{array}{l}\text { There are } 7 \text { pepole } \\
\text { are not AJB Asper } \\
\text { ex }\end{array}$ & $\begin{array}{l}\text { Presentable } \\
\text { Golf qualified } \\
\text { Min D3 } \\
\text { Supple } \\
\text { A good presenter } \\
\text { Having wide product concept }\end{array}$ & $\begin{array}{l}\text { The employee is not civil } \\
\text { servant retired }\end{array}$ \\
\hline
\end{tabular}

Data Source: PT. Asuransi Umum Bumi putera Muda 1967 at Dumai Branch, 2016

According to the above phenomenon, the researcher formulated the symptoms as the company's lack of ability in implementing marketing strategy of promotion decided by the company center. Based on the symptoms stated, the researcher is interested in finding out the implementation of marketing strategy applied by PT. Asuransi Umum Bumi putera Muda 1967 at Dumai Branch.

\section{METHOD}

The method of this research is quantitative design. It was conducted in an insurance company namely PT. Asuransi Umum Bumi putera Muda 1967 at Dumai Branch. Data analysis is a systematically process of triangulation from interview result, field notes, and documentation. Then, the data are transferred into units, analized, and choose the important ones to be interpreted and concluded. This process makes the result understandable.

To analize the primer data, the researcher used descriptive statistical analysis. It is a part of statistical data collection, presentation, and determination statistical units in table presentation. The instrument used to analyze the primer data in this research is likert scale. 


\section{FINDING AND DISCUSSION}

Practicaly, marketing strategy is a series of goal and target, policy and regulation aims at company marketing efforts from time to time. It leads the company reaction to the competition that always changing everytime. The implementation of marketing strategy defines as a tool planned to achieve the company goal is set by developing competitive superior program and marketing program. It is continuously done trough the market enterred. To show us about the result of marketing strategy variable, the following table is presented.

Variable of Marketing Strategy Description

\begin{tabular}{|c|c|c|c|c|c|c|c|c|}
\hline \multirow{2}{*}{ No } & \multirow{2}{*}{ Evaluated Item } & \multicolumn{5}{|c|}{ Options } & \multirow{2}{*}{ Score } & \multirow{2}{*}{ Mark } \\
\hline & & SB & $\mathrm{B}$ & $\mathrm{CB}$ & KB & TB & & \\
\hline 1 & Product & 465 & 328 & 327 & 8 & 3 & 1.131 & Good \\
\hline 2 & Price & 615 & 416 & 450 & 14 & 4 & 1.499 & Good \\
\hline 3 & Place & 515 & 352 & 288 & 8 & 0 & 1.163 & Good \\
\hline 4 & Promotion & 220 & 356 & 405 & 38 & 4 & 1.023 & Good \\
\hline 5 & People & 285 & 308 & 438 & 18 & 2 & 1.051 & Good \\
\hline 6 & Physical Evidence & 380 & 352 & 327 & 28 & 4 & 1.091 & Good \\
\hline 7 & Process & 195 & 372 & 444 & 10 & 6 & 1.027 & Good \\
\hline & Total & 2.675 & 2.484 & 2.679 & 124 & 23 & 7.985 & Good \\
\hline & Option Category & & & & & & Good & Good \\
\hline
\end{tabular}

Source: Analized Data, 2016

The implementation of marketing strategi is one of ways that should get a big attention in every business. After conducting the research, it is found that respondents' attitude (Employee and consumen) towards the product marketing strategy analysis of PT. Asuransi Umum Bumi putera Muda 1967 at Dumai Branch is in category good with the total score 7.985. This score is in range 7.255.6- 8.962.8.

The result shows that the respondens' attitude about the product marketing strategy of PT. Asuransi Umum Bumi putera Muda 1967 at Dumai Branch, based on the total score of questionnaire is in category good with the score 7.985 in percentage $74.83 \%$. The respondents' attitude analysis about product marketing strategy is positive.

There were some factors obstruct the analysis of product marketing strategy of PT. Asuransi Umum Bumi putera Muda 1967 at Dumai Branch. They are:

a. The lack of brochure usage as a tool of promotion

$b$. The lack of socialization in joining the expo handled by Dumai Government.

c. The lack of clarity and a lot of requirements needs to have a claim.

d. The lack of accuracy about particular time in prosessing insurance service. 


\section{CONCLUSION}

The implementation of product marketing strategy in this research is measured by using indicators. They are Product, Price, Place, Promotion, People, Physical Evidence, and Process. Respondents' perception toward the implementation of overall product marketing strategy scored 7.985. It is in good level category with the percentage $74.83 \%$.

The factors influence the analysis of product marketing strategy of PT. Asuransi Umum Bumi putera Muda 1967 at Dumai Branch are as follows:

a. A lot of insurance product as options for consumens.

b. Price transparency in premi payment contract.

c. Wide coverage market area.

The factors obstruct the implementation of product marketing strategy of PT. Asuransi Umum Bumi putera Muda 1967 at Dumai Branch are as follows:

a. The lack of brochure usage in order to promote product marketing strategy.

b. The lack of socialization in joining the expo handled by Dumai Government.

c. The lack of clarity and a lot of requirements needs to have a claim.

d. The lack of accuracy about particular time in prosessing insurance service

\section{SUGGESTION}

Based on the findings, there are suggestions addressed to PT. Asuransi Umum Bumi putera Muda 1967 at Dumai Branch:

1. Eventhough the finding of the research stated that every indicators of marketing strategy of PT. Asuransi Umum Bumi putera Muda 1967 at Dumai Branch is good, it is better for improving the promotion strategy in the next time such as joining expo handled by the government.

2. Management related to claim service should ease the consumen to claim the insurance so the consumens will be comfortable. Management staff has to improve the quality in manage the length of service time. It will ease the new consumen to join the program.

\section{BIBLIOGRAPHY}

[1]. Alma, Buchari. 2014. Manajemen Pemasaran dan Pemasaran Jasa. Bandung: Alfabeta.

[2]. Anoraga, Pandji dan Janti Soegiastuti. 2005. Pengantar Bisnis Modern. Semarang: Pustaka Jaya.

[3]. Assauri, Sofjan. 2010. Manajemen Pemasaran, Dasar, Konsep dan Strategi. Jakarta: Rajawali Pers.

[4]. Bilson Simamora. 2004. Riset Pemasaran: Falsafah, Teori, dan Aplikasi. Jakarta: PT. Gramedia Pustaka Utama.

[5]. Bungin, M. Burhan. 2007. Penelitian Kualitatif; Komunikasi, Ekonomi, Kebijakan Publik, dan Ilmu Sosial Lainnya. Jakarta: Kencana.

[6]. Bungin, M. Burhan, 2009. Penelitian Kualitatif. Jakarta: Kencana

[7]. Darmawi, Herman. 2004. Manajemen Asuransi. Jakarta: Bumi Aksara. 
[8]. Furqon. 2008. Statistika Terapan untuk Penelitian. Bandung: Alfabeta

[9]. Handoko, T. Hani. 2000. Dasar-Dasar Manajemen Produksi dan Operasi. Yogyakarta: BPFE.

[10]. Kotler, Philip. 1991. Marketing. Jakarta: Erlangga.

[11]. Kotler, Philip \& Gery Amstrong. 2008. Prinsip-Prinsip Pemasaran: Edisi 12, Jilid 1. Jakarta: Erlangga.

[12]. Kotler, Philip \& Kevin Lane Keller. 2009. Edisi ke-13. Manajemen Pemasaran. Jakarta: Erlangga.

[13]. Kotler, Philip 2002. Marketing Management (Analysis, Planning, and Control). Jakarta: Erlangga.

[14]. Monroe, Kent. B. 2002. Seri Pemasaran dan Promosi Kebijakan Harga (Pricing Making Profitable Decisions). Jakarta: Elex Media Komputindo.

[15]. Mursid, M. 2008. Manajemen Pemasaran. Jakarta: Bumi Aksara.

[16]. Riduwan. 2007. Pengantar Statistika. Bandung: Alfabeta.

[17]. Riduwan 2011. Dasar-Dasar Statistika. Bandung: Alfabeta.

[18]. Salim, Abbas. 2007. Asuransi dan Manajemen Risiko. Jakarta: PT. Raja Grafindo Persada

[19]. Saputra, T., Marlinda, P., \& Sufi, W. Implementasi Kebijakan Inovasi Pelayanan Publik Di Puskesmas Jaya Mukti Dalam Meningkatkan Kepuasan Masyarakat. Jurnal Niara, 11(2.2019), 177188.

[20]. Siagian, Sondang P. 2004. Manajemen Suatu Pengantar. Bandung: Alumni.

[21]. Sugiyono. 2008. Metode Penelitian Administrasi. Bandung: Alfabeta.

[22]. Sugiyono 2011. Metode Penelitian Administrasi. Bandung: Alfabeta.

[23]. Sutejo, Siswanto. 2003. Kerangka Dasar Manajemen Pemasaran. Jakarta: Binaman.

[24]. Sunyoto, Danang. 2012. Dasar-Dasar Manajemen Pemasaran: Konsep, Strategi, dan Kasus. Yogyakarta: CAPS.

[25]. Sunyoto, Danang. 2015. Strategi Pemasaran. Yogyakarta: CAPS.

[26]. Swastha DH, Basu. 2001. Manajemen Penjualan. Edisi ke-3. Yokyakarta: BPFE.

[27]. Swastha DH, Basu. 2006. Manajemen Pemasaran Analisa Perilaku Konsumen. Jakarta: BPFE.

[28]. Syafiie, Inu Kencana. Welasari. 2015. Ilmu Administrasi. Yogyakarta: PustakaPelajar. 
[29]. Syafiie, Inu Kencana, Tandjung, Jamaluddin \& Modeong. 1999. Ilmu Administrasi Publik. Jakarta: Rinneka Cipta.

[30]. Tjiptono, Fandy. 2008. Strategi Pemasaran. Edisi ke-3. Yokyakarta: Andi Offset.

[31]. Tjiptono, Fandy. 1995. Strategi Pemasaran: Manajemen Jasa, Pemasaran Manajemen. Yogyakarta: Andi Offset. 